\title{
Статистичні методи оцінки природної втрати маси харчових продуктів
}

\author{
Л.М. Пузік, В.К. Пузік \\ Харківський національний технічний університет сільського господарства \\ ім. Петра Василенка (м.Харків, Україна)
}

\begin{abstract}
Розглядаються задачі необхідності вибору та застосування математично-статистичних методів та проведення їх кількісної оцінки, яка необхідна для прийняття рішення щодо можливості їх використання в задачах управління якістю під час зберігання овочевої продукції.

Природний убуток маси виникає на всіх етапах товароруху і $€$ важливою складовою частиною кількісних втрат під час зберігання, транспортування, навантажувально-розвантажувальних робіт, реалізації. Основними причинами виникнення природного убутку маси є: усихання або випарування води; дихання (тільки для продуктів, які відносяться до живих об'єктів); розпилення і розтруска; крихти, які утворюються при продажу товарів (крім карамелі звичайної і цукру-рафрінаду); розлив; видалення леткої фракції речовин; просочування за рахунок вбирання рідкої фракції продуктів тарою, пакувальними матеріалами. При достатньо однорідній генеральній сукупності елементами вибірки слугують типові екземпляри. Партії картоплі, овочів і плодів складаються із фрізіологічно неоднорідних зразків, причому цю неоднорідність іноді важко виявити за зовнішніми ознаками через відсутність об'єктивних критеріїв щодо видів продукції різних культур. У цьому випадку вибірка складається відповідно до принципу випадкового відбору, згідно з яким усі елементи випадкової сукупності мають рівні можливості бути відібраними і вибір здійснюється на вдачу.

Встановлено, що під час зберігання картоплі у штабелях природні втрати залежать від рівня ярусів контейнерів. Найменші втрати маси у першому ярусі штабелю. Зі збільшенням висоти штабелю втрати маси зростають. Для точного виміру втрати маси картоплі сітки для контролю за фактичною збереженістю картоплі, у тому числі і за природними втратами, треба закладати в усіх горизонтальних рядах різних рівнів (ярусами) контейнерів.

Проведені вимірювання дозволяють визначити, яким повинен бути об'єм вибірки, щоб забезпечити вимогливу точність оцінки природного убутку маси.
\end{abstract}

Ключові слова: природний убуток маси, генеральна сукупність, вибірка, зразок, вимірювання.

Постановка проблеми. Природний убуток маси - це зменшення маси нетто харчових продуктів у порівнянні з початковою масою як за рахунок дихального метаболізму та вільної води у живій (свіжій) продукції, так і за рахунок випаровування, розсипу, розпилення, пошкодження зерновими шкідниками, порушення режиму зберігання переробленої продукції. Природний убуток маси встановлюється на стандартну продукцію та визначається в процентах або вагових одиницях. Норму зменшення маси соковитої, зернової і олійної та іншої продукції при тривалому зберіганні диференціюють за ознаками: вид продукції, кліматичні зони, типи сховища, термін зберігання.

Природний убуток маси виникає на всіх етапах товароруху і $\epsilon$ важливою складовою частиною кількісних втрат під час зберігання, транспортування, навантажувально-розвантажувальних робіт, реалізації. Основними причинами виникнення природного убутку маси є: усихання або випарування води; дихання (тільки для продуктів, які відносяться до живих об'єктів); розпилення і розтруска; крихти, які утворюються при продажу товарів (крім карамелі звичайної і цукрурафрінаду); розлив; видалення леткої фракції речовин; просочування за рахунок вбирання рідкої фрракції продуктів тарою, пакувальними матеріалами [1]. Для різних продовольчих товарів доля впливу вказаних причин на величину природних втрат маси неоднакова. Найбільша питома вага всіх харчових продуктів приходиться на усихання або випарування води (70 - $100 \%)$. У таких продуктів, як м'ясо, риба, харчові жири, молочні товари (сир), багато кондитерських виробів, природній убуток маси обумовлений, в основному, втратами за рахунок води [2].

Природний убуток маси свіжих плодів і овочів обумовлений на 70-95 \% випаруванням води, а 5-30 \% припадає на витрату сухих речовин унаслідок дихання. У квашених овочів і мочених плодів і ягід природний убуток маси виникає за 
рахунок випарування води і видалення газоподібних речовин (витискування повітря з тканин розсолом, видалення газів, що утворилися при бродінні), а також за рахунок усмоктування розсолу квашеної капусти і іншої продукції стінками дерев'яної тари.

Харчові продукти з порошкоподібною структурою (борошно, крохмаль, цукрова пудра і т. ін.) втрачають масу не тільки за рахунок випарування води, але і розпилення, а також потрапляння часток продукту на поверхню тари та пакувальних матеріалів.

За наявності в твердих продуктах легковідокремлюваної рідкої фрракції (найчастіше рідких жирів) можуть бути кількісні втрати за рахунок усмоктування її стінками тари та пакувальними матеріалами. До таких продуктів належить халва (рідка фрракція - рідкі жири), масло коров'яче (виділення пахти, особливо при механічній дії, а також рідкої фракції жирів), м'ясокопченості, солона і копчена риба (виділення жиру).

Величина природної втрати маси залежить від інтенсивності процесів, які обумовлюють об'єктивні причини виникнення природного убутку маси. У свою чергу інтенсивність вказаних процесів визначається фізичними і хімічними властивостями продукту, а також умовами зберігання.

Природного убутку маси немає у товарів в герметичній тарі, тому що паро- і газоподібні продукти, що при цьому виробляються, залишаються в тарі і не втрачаються [3].

Аналіз результатів останніх досліджень. Убуток маси є важливим показником якості всіх харчових продуктів, а особливо соковитої сировини. При збільшені водного дефріциту посилюється випаровування, черствіння хлібобулочних виробів, втрата тургору у плодоовочевій продукції.

Природний убуток маси визначається з використанням процедури вибіркового обстеження, яке ми розглянемо на прикладі плодоовочевих баз. Усю сукупність картоплі, овочів і плодів, призначених для закладання на зберігання, називають генеральною сукупністю. Зразки, відібрані із генеральної сукупності для проведення обстеження, складають вибірку [4-6].

Якщо генеральна сукупність достатньо однорідна, то елементами вибірки слугують типові екземпляри. Але, як правило, партії картоплі, овочів і плодів складаються із фрізіологічно неоднорідних зразків, причому цю неоднорідність іноді важко виявити за зовнішніми ознаками через відсутність об'єктивних критеріїв щодо видів продукції різних культур. У цьому випадку вибірка складається відповідно до принципу випадкового відбору, згідно з яким усі елементи випадкової сукупності мають рівні можливості бути відібраними і вибір здійснюється на вдачу.
Кожен із вибраних зразків може бути представлений або одиничним екземпляром (один плід або овоч), або декількома екземплярами (4,5,10 - залежно від їх величини і наявності), або тарними одиницями (мішками, сітками, ящиками, контейнерами) [7]. Залежно від виду плодоовочевої продукції вибирають способи визначення природного убутку маси. Способи поділяють на моноекземплярний, поліекземплярний і тарний. Усі вони мають свої переваги і недоліки [8].

Моноекземплярний спосіб дозволяє збільшити кількість повторень і їх однорідність при невеликій кількості овочів і плодів, підвищити точність визначення за рахунок застосування більш чутливих терезів. Можливість підвищення точності вимірювання знижує процент систематичних помилок. Проте цей спосіб найбільш придатний для визначення природного убутку в лабораторних умовах або екземплярів продукціїз великою масою (гарбузи, кавуни, великі головки капусти). Застосуванняйого у виробничих умовах плодо- і овочесховищ і для плодів, і для овочів 3 малою масою викликає труднощі, оскільки робота електронних та інших точних терезів потребує постійного місця роботи, низького рівня забруднення оточуючого повітря пилом, стабільності температурно-вологісного режиму.

Поліекземплярний спосіб має більші практичні переваги у порівнянні з моноекземплярним при проведенні досліджень у виробничих умовах.

Оскільки кількість екземплярів в одному зразку збільшується у 5-10 разів, відбувається додаткове визначення значень досліджуваного показника й у випадку якісно неоднорідної продукції окремі зразки виявляються більш однорідними, ніж при моноекземплярному способі відбору. В цьому випадку використовують ваги 3 меншою точністю (з ціною ділення 10 г).

Відбір зразків при моно- і поліекземплярному методах потребує обережного сортування продукції, щоб не нанести механічних пошкоджень, і дає змогу визначити природний убуток тільки стандартної продукції.

При вказаних способах зразк розміщають в пакувальну пронумеровану полімерну сітку, тому що вона не зволожується. Обов'язковою умовою при поліекземплярному способі $є$ однакове число екземплярів, до того ж це дає можливість визначити середнюмасу зразків під час закладання і кожного чергового зважування.

Тарний спосіб визначення дозволяє встановити природний убуток маси різноякісної продукції, тому процент випадкових помилок тут може бути дуже великим. Проте для деяких видів плодоовочевої продукції він $€$ найбільш придатним у виробничих умовах, бо плоди й овочі 3 низькою механічною стійкістю тканин при зберіганні потребують захисту від механічних дій 
шляхом розміщення в тарі. Періодична виїмка 3 тари, тиск пальців на поверхню плоду може викликати появу натисків, давлення ягід, унаслідок чого зростає не тільки убуток маси, але й актовані втрати.

Вказані фрактори є найбільш важливими і це спонукає до знехтуванняіншими фракторами, які знижують точність визначення: низькою точністю зважування (коли застосовують ваги з ціною ділення 100 г і більше), відносною неоднорідністю продукції, обумовленою вмістом дефектної і бездефектноїпродукції, наважками за масою брутто і встановленням маси нетто, як різниціміж фактичною масрю брутто та усередненою масою тари разом з пакувальним матеріалом.

При тарному способі поряд з випадковим використовують механічний відбір зразків. Із послідовності тарних місць, які входять в генеральну сукупність, відбираються одиниці, які мають визначні порядкові номера, наприклад 1 a, 11 a, 21 a i т. Ін. [9].

Отже, у виробничих умовах краще застосовувати поліекземплярний спосіб при визначенні природного убутку маси горіхів і овочів з високою механічною стійкістю тканин і порівняно невеликою масою (картоплі, коренеплодів, капусти, цибулевих овочів, овочевої зелені, перця, баклажанів), моноекземплярний - для овочів з великою масою (більше 1,5-2,0 кг). Для плодів і деяких плодових овочів (томатів) доцільно застосовувати тарний метод.

При відборі зразків необхідно враховувати їх просторове розподілення в сховищі, камерах холодильника, щоб типові зразки були вибрані з різних місць, бо розташування зразків у тому або іншому місці сховища може мати істотне значення для природного убутку маси.

Дослідні зразки повинні бути розміщені в тимчасових сховищах таким чином. У буртах 3 північного боку внизу, усередині і по гребню бурта, тобто у п'яти місцях по три. У траншеях також у такій кількості, а саме: по дну збоку від стінки, з південної сторони посередині і зверху над стінкою - з північної сторони. У стаціонарних сховищах - у різних місцях, що охопили різні умови температури і вологості.

Однак цей спосіб не єдиний. Застосовуються й інші способи: розташування в одному місці сховища в трьох точках за висотою; в одному місці в одній точці; в 12-ти точках (в центрі, біля дверей, близько від охолоджуючих приладів, якомога далі від них 3 розташуванням по вертикалі: зверху, усередині, внизу). Указані способи розміщення зразків відрізняються працевмісткістю, впливом випадкових і систематичних помилок, кількістю закладених зразків. Критерієм їх вибору повинна стати мета експериментального визначення природної втрати маси.
Методи закладення зразків в 12-ти і 5-ти точках (типу конверта) вимагають деякого підпорядкування технологічного циклу виробничого зберігання експериментальної мети: одночасного завантаження всього сховища або хоча б окремих місць, де будуть розташовані дослідні зразки; доступу до них в період зберігання, одночасного і не розтягнутого в часі розвантаження сховища.

Перевагою методу є запобігання систематичним помилкам за рахунок обліку неоднакової збереженості продукції в різних частинах складу сховища, холодильної камери, викликаної градієнтом вертикальних і горизонтальних температур [10].

Указані методи доцільно застосовувати при визначенні норм природного убутку маси, розповсюджених на всі подібні типи сховищ, а також природного убутку як одного з важливих показників збереженості плодоовочевої продукції для встановлення технологічних особливостей сховищ данного типу і покращання в них режиму оптимізації розташування.

Для порівняльного дослідження інших фракторів, що обумовлюють величину природного убутку маси, до числа яких відноситься якісний стан продукції (форма, величина, забарвлення, ступінь стиглості, наявність дефектів, умови вирощування або товарної обробки), способи розміщення, різниці в показниках режиму зберігання (температури, відносної вологості, газового складу, повітрообміну та освітлення), дослідні зразки можливо розміщати в одній або трьох вертикальних точках камери зберігання (сховища).

Розподіл n-зразків у різних точках сховища $\left(n_{1}, n_{2}, n_{3}\right.$, і т. д.) повинно бути рівномірним, але не менше трьох у кожній точці з тим, щоб в сумі було не менше 10 при поліекземплярному і не менше 15 при тарному способах визначення.

Дослідні, зважені з точністю до 1 г, зразки, при моно- або поліекземплярному способах визначення розміщаються насипом продукції (верх, середина, низ, від верху не менше ніж 0,3 м у глибину), а при зберіганні основної маси продукції в тарі (ящиках, лотках, контейнерах, сітках) зразки розміщують в тару. При такому способі визначення дослідні пронумеровані тарні одиниці розміщуються тим способом, який застосовується в цьому сховищі або прийнятий для дослідження.

Зважування дослідних зразків при закладанні і чергових зніманнях для обліку проводять на одних і тих самих терезах, точність вимірювання яких перевіряється встановленими способами перед початком зважування. На результати вимірювань можуть впливати помилки трьох типів: грубі, систематичні і випадкові.

Грубі помилки можуть виникати внаслідок порушення основних умов вимірювання через нео- 
бережність експериментатора. При цьому виникають різні результати, ознакою яких $€$ їх різка відмінність від інших вимірювань. Такий сумнівний результат необхідно перевірити і повторити зважування зразка [11].

Систематичні огріхи викликаються визначними причинами, величина їх залишається звичайно постійною при повторних вимірюваннях. Наприклад, особливістю деяких партій картоплі і коренеплодів, які надходять на зберігання восени, $є$ сильне забруднення і зволоження продукції. Відбір такої продукції для визначення природного убутку маси може привести до виникнення значних систематичних помилок за рахунок підсихання поверхневої вологи і відпадання частини прилиплої землі. Для усунення цих помилок необхідно поверхню дослідної продукції обсушити і обережно відокремити від прилиплої землі (мити продукцію не рекомендується, тому що якісний стан ії зміниться).

Якщо не була проведена ця попередня обробка зразків, результати досліджень, проведених восени, матимуть систематичну помилку у порівнянні з даними подібних експериментів, проведених над зразками, відібраними в інший сезон, наприклад, весною. Більш того, для різних партій коренеплодів, які надішли восени, спостерігається більший розкид в значеннях убутку маси залежно від того, суха чи дощова була осінь.

До систематичних помилок приводить також порушення регулювання терезів, при якому в ненавантаженому стані стрілка покажчика знаходиться не на нулю. Прикладом систематичної помилки є будь-яке округлення числа. Якщо експериментальні дані наводяться без вказівки на помилку, то вважається, що ця помилка становить $\pm 0,5$ останньої значущої цифри. Знаючи причини, які викликають систематичні помилки, можна їх усунути шляхом введення відповідних поправок у результаті вимірювання [12].

На значення природного убутку маси впливає велика кількість фракторів, відфрільтрувати які неможливо; а саме: коливання температури i відносної вологості повітря, фрізіологічна і якісна неоднорідність продукції, нерівномірність потоків повітря при різних системах вентилювання тощо. Сумарний ефект дії цих фракторів приводить до випадкових помилок. Тому поява того чи іншого значення вимірюваної величини при зважуванні також $є$ випадковою подією. Випадкові помилки трапляються в окремих результатах вимірювання, але методами математичної статистики можна врахувати їхній вплив на оцінку істинного значення вимірюваної величини.

При вибірковому обстеженні із великої партії овочів і плодів, які складають генеральну сукупність, вибирається деяка частина. Після вимірювання природного убутку маси зразків, які входять у вибірку, одержують відповідні оцінки для всієї партії товару.

На практиці схема вибіркового обстеження $€$ основною і часто єдино можливою. Вона вимагає значно менше витрат робочого часу і коштів, ніж суцільне обстеження, але має один суттєвий недолік: результати, одержані на основі обстеження вибірки, випадково відхиляються від істинних значень природного убутку маси всій партії товару. Будь-які прогнози про властивості і параметри генеральної сукупності $€$ наближеними і навіть при найкращих способах формування вибірки деякий ступінь точності втрачається. Для того щоб за даними вибірки можна було достатньо впевнено встановити значення природного убутку маси для всієї генеральної сукупності, необхідне достатнє представництво вибірки, що дасть змогу з потрібною точністю оцінити істинні значення.

Мета роботи статистичним методом оцінити природну втрату маси харчових продуктів на основі представницької вибірки

Методика визначення оцінки природної втрати маси харчових продуктів

В процесі обробки одержаних даних про зміну маси продовольчих товарів під час зберігання вираховують такі статистичні характеристики $[13,14]$.

Природний убуток маси одиничних зразків:

$$
x_{\mathrm{i}}=\frac{m_{0}-m_{1}}{m_{0}} 100 \%,
$$

де $m_{0}$ і $m_{1}$ - початкова і кінцева маса зразка; г.

2. Середнє значення природного убутку для вибірки:

$$
\bar{x}=\frac{\sum_{i=1}^{n} x_{i}}{n}
$$

де $n$ - кількість зважених контрольних зразків, відібраних у вибірку.

\section{3. Середнє квадратичне відхилення:}

$$
\delta=\frac{\sqrt{\sum_{i=1}^{n}\left(x_{1}-\bar{x}^{2}\right)}}{n} .
$$

Величина квадратичного відхилення дозволяє оцінити ступінь розкиду значень природного убутку маси одиничних зразків щодо середнього значення. Якщо об'єм вибірки малий $(n<30)$, то замість $\delta$ вираховують емпіричний стандарт $S$, який у цьому випадку $є$ більш точною характеристикою, ніж $\delta$ :

$$
S=\sqrt{\left(\frac{1}{n-1}\right) \sum_{i=1}^{n}\left(x_{1}-\bar{x}\right)^{2}}
$$


4. Точність оцінки природного убутку 3 урахуванням помилки терезів $\delta$ і заданої надійності $\vartheta$ :

$$
\Delta=\sqrt{\frac{t^{2}(\gamma, k) S^{2}}{n}+\frac{t^{2}(\gamma, \infty)}{9}},
$$

де $k=n-1 ; t(\gamma, k)$ - критерій Стьюдента; $t(\gamma, \infty)$ - значення критерію Стьюдента для $k \rightarrow \infty$

При експериментах на харчових продуктах надійність оцінки звичайно приймають рівною 0,95 . Це означає, що значення природного убутку повинно бути надійним у 95 випадках із 100 розглянутих.

Зважування проводять на терезах з ціною поділки 28 г. Погрішність терезів становить \pm 8 г, що дорівнює половинці ціни найменшої поділки шкали терезів. Виникає питання, як впливає погрішність терезів на точність оцінки природного убутку маси продуктів? Аналіз формули (5) свідчить про те, що якщо емпіричний стандарт, вирахуваний за даними вимірів, виявиться менше погрішності терезів, то відпадає сенс шляхом збільшення об'єму вибірки пробувати зменшити величину випадкової погрішності, одержаної через розкид окремих вимірювань відносно середнього значення вимірювань, і результати вимірювань не стануть від цього більш точними.

Але якщо емпіричний стандарт $S$ більше погрішності терезів $\delta$, то маємо резерв для зменшення значень випадкової погрішності (за рахунок збільшення числа вимірювань) до тих пір, поки $S$ стане дещо меншим або одного порядку з погрішністю терезів. Якщо погрішність, яка вноситься терезами, суттєво менша $S$, точність оцінки $\Delta$ можна оцінити за формулою:

$$
\Delta=t(\gamma, k) \frac{S}{\sqrt{n}} .
$$

5. Довірчий інтервал:

$$
\bar{x}-\Delta<x<\bar{x}+\Delta,
$$

де $x$ - істинне значення природного убутку маси харчових продуктів.

Суть довірчого інтервалу полягає в тому, що гарантована надійність $\vartheta$. Істинне значення природного убутку маси відрізняється від середнього значення $\bar{x}$, одержаного для відібраної вибірки, не більше ніж на величину $\Delta$. Із зростанням надійності $ү$ ширина довірчого інтервалу збільшується.

На практиці завдання звичайно ставиться так: апріорі відомо, 3 якою точністю $\Delta$ треба визначити значення природного убутку. Мінімальну кількість вимірювань, яка потребується для досягнення вимог точності $\Delta$ із заданою надійністю $\vartheta$, можна оцінити за фрормулою:

$$
n=\frac{[t(\gamma)]^{2} \sigma_{r}^{2}}{\Delta^{2}}
$$

де значення $\mathrm{t}(\gamma)=2,5$ при $\gamma=0,95 ; \sigma_{r}$ - оцінка середнього квадратичного відхилення, яка відома із теоретичного уявлення або взята для цієї партії овочів і плодів за відомими аналогами продукції. Якщо $\sigma_{r}$ наперед не відома, проводиться оціночний експеримент на невеликій кількості зразків. Якщо при цьому експерименті були проведені зважування і виявлено точність оцінки, то для забезпечення заданої точності $\Delta$ треба провести додаткові зважування так, щоб загальна кількість зразків становила:

$$
n=n_{\text {оц }}\left(\frac{\Delta_{\mathrm{оц}}}{\Delta}\right)^{2}
$$

Таким чином, зменшення довірчого інтервалу в $k$ разів забезпечується збільшенням кількості вимірювань в $k^{2}$ разів.

Результати вимірювань треба попередньо проаналізувати, щоб відфільтрувати відомі неправильні результати, які можуть дати помилкові середні значення природного убутку маси і межі довірчого інтервалу. Питання про доцільність відкидання сумнівного результату вирішується 3 використанням $\mathrm{t}$-критерію за відношенням:

$$
t=\frac{x^{*}-\bar{x}}{S}
$$

де $x^{*}$ - сумнівний результат, який помітно відрізняється від результатів інших вимірювань; $\bar{x}$ - середнє значення інших $\mathrm{n}$ результатів; $S$ - емпіричний стандарт, який визначається за формулою (4).

Розрахункові значення $t$ порівнюють 3 критичним значенням $\mathrm{t}_{\mathrm{n}}(\gamma)$ (для надійності висновку $\gamma=0,95$. У разі, якщо надійність перевищує 0,95, вважається, що $x^{*}$ містить грубу помилку і $x^{*}$ виключається з подальшої обробки результатів.

При проведенні досліджень визначають вплив на природний убуток маси різних факторів. Наприклад, як впливають різні режими зберігання або технологія обробки продуктів перед закладанням на зберігання. Ефект дії факторів, що цікавлять експериментатора, виявляється шляхом порівняння середніх значень природного убутку для двох вибірок так, щоб зразки, які входять в одну вибірку, відчували вплив цього фактора, а в другій вибірці такий вплив був відсутнім.

При цьому необхідно встановити, чи $\epsilon$ різниця між порівнюваними значеннями природного убутку маси для двох вибірок випадковою чи вона обумовлена дією досліджуваного фактора. Для вирішення цього питання вираховують відношення: 


$$
t=\frac{\overline{x_{2}}-\overline{x_{1}}}{S \sqrt{\frac{1}{n_{1}}+\frac{1}{n_{2}}}}
$$$$
\text { де } \quad S=\sqrt{\frac{\left(n_{1}-1\right) S_{1}^{2}+\left(n_{2}-1\right) S_{2}^{2}}{n_{1}+n_{2}-2}},
$$

де $\bar{x}(i=1,2)$ - середнє значення природного убутку відповідно для першої і другої вибірок; $S_{1}, \quad S_{2}$ - відповідні емпіричні стандарти; $n_{1}, n_{2}-$ кількість зразків у вибірках.

У подальшому для заданої надійності $\gamma$ i числа ступенів волі $k=n_{1}+n_{2}-2$ визначають критерій Стьюдента $t(\gamma, k)$.

Якщо $|t|>t(\gamma, k)$. То розбіжність середніх значень $\overline{x_{1}}$ i $\overline{x_{2}}$ можна вважати невипадковим. У противному разі не можна вважати цю розбіжність значною і можна пояснити різницю $\overline{x_{1}}$ і $\overline{x_{2}}$ впливом випадкових помилок.

Викладення результатів досліджень. Застосування вищевикладених загальнометодичних підходів до визначення природних втрат плодоовочевих товарів розглянемо на прикладі статистичної обробки даних при аналізі впливу на природні втрати маси картоплі, умов зберігання, залежно від місця знаходження контейнера в штабелі бульб. Відомо, що в сховищі існує градієнт температури, а тому температура, а отже, і відносна вологість повітря в зоні підлоги і в зоні перед стелею можуть відрізнятися на $2 \ldots 3^{\circ} \mathrm{C}$, а тому сітки для контролю за фрактичною збереженістю картоплі, у тому числі і за природними втратами, треба закладати в усіх горизонтальних рядах різних рівнів (ярусами) контейнерів.

В табл. 1 наведені значення природного убутку для картоплі з першого, другого і третього ярусів контейнерів, розташованих в картоплесховищі.

Таблиця 1. Природний убуток маси згідно зі зваженими контрольними зразками закладених у трьох ярусах контейнерів, \%

\begin{tabular}{|c|c|c|c|c|c|c|c|c|c|c|c|}
\hline \multirow{2}{*}{ 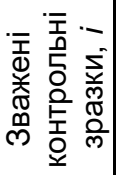 } & \multicolumn{10}{|c|}{ Номери контрольних зразків } & \multirow{2}{*}{$\frac{\frac{0}{1}}{\frac{1}{W}}$} \\
\hline & - & $N$ & m & $\nabla$ & 10 & 0 & $\Lambda$ & $\infty$ & $\sigma$ & 음 & \\
\hline$x_{i 1}$ & O. & $\begin{array}{l}\stackrel{+}{+} \\
\end{array}$ & $\begin{array}{l}\infty \\
\aleph^{-}\end{array}$ & $\begin{array}{l}\Omega \\
10\end{array}$ & $\begin{array}{l}\infty \\
\infty\end{array}$ & $\begin{array}{l}\infty \\
\omega^{\prime \prime}\end{array}$ & $\begin{array}{l}\Omega \\
\forall\end{array}$ & $\sqrt{0^{\circ}}$ & $\begin{array}{l}0 \\
0 \\
\end{array}$ & $\bar{\kappa}$ & $\begin{array}{l}\Omega \\
\stackrel{n}{n}\end{array}$ \\
\hline$x_{i 2}$ & $\hat{\sim}$ & $\begin{array}{l}0^{0} \\
\infty\end{array}$ & $\begin{array}{l}\text { O } \\
\forall\end{array}$ & $\stackrel{\text { s) }}{\sim}$ & $\begin{array}{l}\sigma \\
\text { का }\end{array}$ & $\begin{array}{l}\sigma \\
\infty\end{array}$ & $\stackrel{m}{\sim}$ & $\begin{array}{l}\stackrel{+}{0} \\
\dot{0}\end{array}$ & $\overbrace{}^{\infty}$ & $\stackrel{m}{N}$ & $\overline{10}$ \\
\hline$x_{i 3}$ & $\begin{array}{l}\infty \\
0^{-}\end{array}$ & $\begin{array}{l}0 \\
0 \\
0\end{array}$ & $\begin{array}{l}\infty \\
\omega^{-\infty}\end{array}$ & $\begin{array}{l}\mathscr{6} \\
\infty\end{array}$ & 5 & (2) & $\hat{=}$ & $\begin{array}{l}\infty \\
\infty \\
\infty\end{array}$ & $\bar{\sigma}$ & $\bar{\sigma}$ & $\mathscr{\varnothing}$ \\
\hline
\end{tabular}

$x_{i k}(k=1,2,3)$ - значення природного убутку для i-го зваженого зразка $(\mathrm{i}=1 \ldots, 10)$ на $k$-му ярусі.
Згідно з формулою (2) вибіркове середнє значення природного убутку маси для першого ярусу становить:

$$
\bar{x}=\frac{\sum_{i=1}^{10} x_{i 1}}{10}=\frac{57,9}{10}=5,8 \% .
$$

При цьому емпіричний стандарт за формулою (4) дорівнює:

$$
S_{2}=\sqrt{\frac{\sum_{i=1}^{10}\left(x_{i 2}-5,8\right)^{2}}{9}}=\sqrt{\frac{17,61}{3} \cong 1,40 \%} .
$$

Для $k=9$ і надійності $\gamma=0,95$ значення критерію Стьюдента $t(\gamma, k)=2,262$. Розкид окремих вимірювань навколо середнього значення $\bar{x}$ великий, тому точність оцінки природного убутку $\Delta_{1}$ можна визначити за формулою (6):

$$
\Delta_{1}=\frac{2,262 \cdot 1,4 \%}{3}=1,1 \% \text {. }
$$

Отже, з надійністю 0,95 можна вважати, що значення природного убутку маси знаходиться в інтервалі

$$
(5,8-1,1) \%<x_{2}<(5,8+1,1) \%,
$$

тобто

$$
4,7<x_{2}<6,9 .
$$

Оскільки довірчий інтервал виявився надто широким, для підвищення точності оцінки були проаналізовані результати вимірювання з метою відкидання помилкових даних, які могли різко змінити як середнє значення $\bar{x}$, так і точність оцінки $\Delta_{1}$. Сумнівними представляються значення, $x_{52}=8,8 \%, x_{32}=3,8 \%, x_{102}=7,1 \%$, які достатньо різко відрізняються за величиною від результатів останніх вимірювань.

Якщо не враховувати результат п'ятого вимірювання $\quad x_{52}=8,8 \%$, то одержимо $x_{2}=5,5 \%, S_{2}=0,95 \%, \Delta_{1} \approx 0,8 \%$.

Значення $t$-критерію, вирахованого за формулою (9), становить:

$$
t=\frac{8,8-5,5}{0,95} \cong 3,47 .
$$

Згідно з критичним значенням $t_{9}(0,95)=2,43$. Якщо розрахункове значення $3,47>2,43$, то можна вважати, що $x_{52}=8,8 \%$ містить грубу помилку і це значення потрібно виключити з розгляду. Отже, істинне значення убутку маси картоплі знаходиться в інтервалі:

$$
4,7 \%<x_{2}<6,3 \% \text {. }
$$

Якщо не враховувати результат третього вимірювання $x_{32}=3,8 \%$, то одержимо $\bar{x}_{2} \approx 5,7 \%$; $S_{2}=0,8$. Для цього випадку розрахункове значення $t$ - критерію складає $t=(5,7-3,8) / 0,8 \cong 2,38$. 
Критичне значення $\mathrm{t}_{8}(0,95=2,51>2,38)$, тому у даній серії спостережень немає підстав вважати значення $x_{32}=3,8 \%$, помилковим; виключати це значення з розгляду не треба.

Якщо враховувати результат десятого вимірювання $x_{102}=7,1 \%$, то одержимо $\bar{x}_{1}=5,2$; $S_{1}=0,80$. При цьому $t=2,38<t_{g}(0,95)$. Отже, значення також треба враховувати.

Таким чином, для вибірки, яка містить картоплю $з$ першого ярусу штабеля, треба враховувати результати дев'яти вимірювань. При цьому вибіркове середнє значення убутку маси становить $\bar{x}_{1}=5,5 \%$ і довірчий інтервал дорівнює $4,7 \%<x_{2}<6,3 \%$. Ширина довірчого інтервалу залежить від заданої надійності. Якщо прийняти $\gamma=0,90$, то для розглянутого випадку одержимо $\Delta_{1}=0,6 \%$. Проведені вимірювання дозволяють визначити, яким повинен бути об'єм вибірки, щоб забезпечити вимогливу точність оцінки природного убутку маси. Наприклад, якщо необхідно зменшити ширину довірчого інтервалу так, щоб величина $\Delta_{1}$ була не більше 0,5 \% при заданій надійності висновку 0,95, треба додатково дослідити 14 зразків.

Таблиця 3. Значення крітерію F на 5\%-вому рівні значимості (вірогідність 95\%)

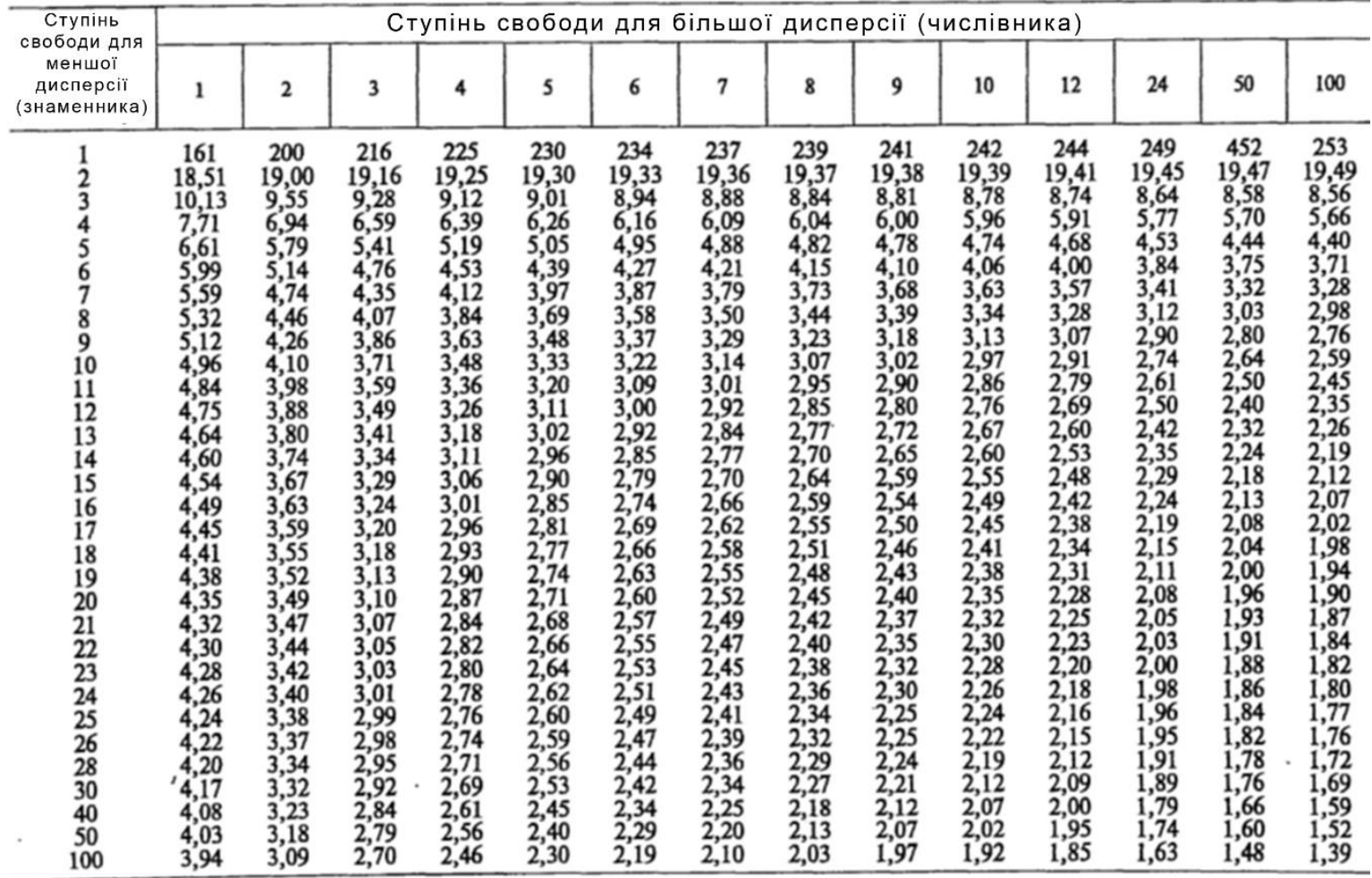

Попередній аналіз даних, одержаних для картоплі другого ярусу, показав, що з надійністю висновку, переважаючою 0,95, два результати вимірювання $\mathrm{x}_{13}$ і $x_{43}$ треба виключити з розгляду. При цьому вибіркове середнє значення за результатами останніх восьми вимірювань становить $7,4 \%$, емпіричний стандарт $S_{3}=1,6$; точність оцінки $\Delta_{3}=1,3 \%$.

Для вибірки з третього ярусу був виключеним результат сьомого вимірювання $x_{74}=1,7$. Вибіркове середнє $\bar{x}_{g}=7,0 \%$; емпіричний стандарт $S_{g}=1,44$; точність оцінки $\Delta_{g}=1,1 \%$.

Було досліджено, чи є наслідком впливу випадкових похибок розходження між середнім значеннями убутку маси картоплі для розгляду трьох вибірок чи воно обумовлене різними особливостями умов зберігання в картоплесховищі.
Для цього виконали підрахунки за фрормулою:

$$
\begin{gathered}
t_{p m}=\frac{\overline{x_{p}}-\overline{x_{m}}}{S_{p m} \sqrt{\frac{1}{n_{p}}+\frac{1}{n_{m}}}} \\
S_{p m}=\sqrt{\frac{\left(n_{p}-1\right) S_{p}^{2}+\left(n_{m}-1\right) S_{m}^{2}}{n_{p}+n_{m}-2}},
\end{gathered}
$$

де $p, m$ - номери ярусів. Послідовно були розглянуті випадки: $(p=1 ; m=2) ; \quad(p=1 ; m=3)$; $(p=2 ; m=3) ; n_{p}, n_{m}$ - кількість врахованих результатів вимірювань у відповідних вибірках.

Одержані значення наведені в табл. 3. 
Таблиця 3. Розходження між середніми значеннями убутку маси картоплі для розгляду трьох вибірок унаслідок впливу випадкових похибок

\begin{tabular}{|c|c|c|c|}
\hline Показник & $\begin{array}{c}p=1 \\
m=2\end{array}$ & $\begin{array}{c}p=1 \\
m=3\end{array}$ & $\begin{array}{c}p=2 \\
m=3\end{array}$ \\
\hline & 15 & 16 & 15 \\
\hline$S_{p m}, \%$ & 1,40 & 1,28 & 1,61 \\
\hline$t_{p m}$ & 2,71 & 2,26 & 0,50 \\
\hline$t_{(0,95 k)}$ & 2,160 & 2,145 & 2,160 \\
\hline
\end{tabular}

Порівняння розрахункових значень $t_{p m}$ з критерієм Стьюдента $t_{(0,95 k)}$, свідчать про те, що розходження середніх значень природного убутку маси картоплі з першого і другого ярусів, а також з першого і третього ярусів можна вважати невипадковими. Розходження середніх значень убутку маси картоплі з другого і четвертого ярусів можна пояснити впливом випадкових помилок.

Дані математичної обробки були зведені в табл. 4 і проаналізовані 3 точки зору кращого вибору ярусу для скорочення витрат, прийняття організаційних рішень. Ці дані свідчать, що умови зберігання картоплі на першому ярусі сприяють скороченню втрат до 5,5 \%, тобто різниця між першим і другим, і третім ярусами становить 1,5$1,9 \%$. Як відмічалося вище, ця різниця невипадкова, про що свідчать розрахункові значення $t_{p m}$.

Таблиця 4. Вибір ярусу для скорочення витрат i прийняття організаційних рішень

\begin{tabular}{|c|c|c|c|}
\hline$\underset{\text { 음 }}{\stackrel{0}{\alpha}}$ & $\begin{array}{c}\text { Вибіркове середнє } \\
\text { значення природного } \\
\text { убутку маси, \% }\end{array}$ & 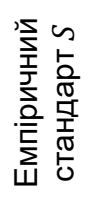 & 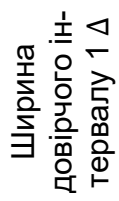 \\
\hline 1 & 5,5 & 0,95 & 1,60 \\
\hline 2 & 7,4 & 1,60 & 2,60 \\
\hline 3 & 7,0 & 1,44 & 2,20 \\
\hline
\end{tabular}

Зменшений природний убуток збігається 3 меншим розкиданням одиничних замірів природного убутку від вибіркового середнього, що також підтверджує припущення доцільності зберігання картоплі на першому ярусі, зокрема для тривалого зберігання.

Проведені на першому ярусі заміри природного убутку маси мають більш вузький довірчий інтервал, ніж заміри на другому і третьому яруcax. Найвищий природний убуток з найбільшим розкидом даних при найменшій точності оцінки має картопля з другого ярусу, але різниця між другим і третім ярусами, як показали розрахунки, недостовірна, отже, нею можна нехтувати.
Проведений аналіз свідчить про те, що для скорочення природного убутку маси найбільш придатні умови зберігання першого ярусу, де картоплю можна зберігати більш тривалий термін.

Висновки. Встановлено, що під час зберігання картоплі у штабелях природні втрати залежать від рівня ярусів контейнерів. Найменші втрати маси у першому ярусі штабелю. Зі збільшенням висоти штабелю втрати маси зростають. Для точного виміру втрати маси картоплі сітки для контролю за фактичною збереженістю картоплі, у тому числі і за природними втратами, треба закладати в усіх горизонтальних рядах різних рівнів (ярусами) контейнерів.

Проведені вимірювання дозволяють визначити, яким повинен бути об'єм вибірки, щоб забезпечити вимогливу точність оцінки природного убутку маси.

\section{Література}

1. С. Децюра. Втрати сільгосппродукції при зберіганні: відображаємо операції в обліку https:// ibuh.info / vtrati-silgospprodukci\%D1\%97-pri-zberig anni-vidobrazhayemo-operaci\%D1\%97-v-obliku

2. Жук Ю.Т. Теоретичні основи товарознавства / Ю.Т. Жук, В.А. Жук, В.В. Гаврилишин та ін. / Підручник. - Львів: Компакт-ЛВ, 2009. - 480 с.

3. В.А. Колтунов, Є.В. Бєлінська Технологія зберігання продовольчих товарів навчальний посібник «Видавництво «Центр учбової літератури» Київ 2014. - 135с.

4. Колтунов В.А. Технологія зберігання продовольчих товарів: лабораторний практикум /В.А. Колтунов. - К. : КНТЕУ,2003. - 341 с.

5. Николаева М. А. Теоретические основы товароведения : учеб. Для вузов / М.А. Николаева. - М.: Норма, 2007. - 448 с.

6. Бузукова Е.А. Ассортимент розничного магазина: Методы анализа и практические советы. / Е.А. Бузукова. - СПб.: Питер, 2007. - 176 с.

7. Головач А.В., Захожай В.Б., Головач Н.А. Статистичне забезпечення управління економікою: прикладна статистика: Навчальний посібник. К: КНЕУ, 2005. - 408 с.

8. Матковський С.О., Марець О.Р. Теорія статистики: Навч. посібник. - К.: Знання, 2010. $-534 \mathrm{c}$.

9. Лудченко О.А. Основи наукових досліджень і патентознавство: навч. посібник /О.А. Лудченко, Ю.Г. Сухенко, Я.О. Лудченко, В.Ю. Сухенко. - 4-те вид., перероб. І доп. - К. : ВДК «Україна», 2011. - 237 с.

10. В.А. Колтунов Наукові дослідження у товарознавстві сільськогосподарських продуктів Монографія. /В.А. Колтунов, Л.М. Пузік, Е.Р. Ермантраунт, В.Я. Плахотін Харків, ФОП Іванченко, $2016,-235$ c. 
11. Методы исследований и организация экспериментов /под ред. К.П. Власова - Х.: Гуманит. Центр, 2002. - 256 с.

12. Білецький В. С., Смирнов В. О. Моделювання процесів збагачення корисних копалин: (Монографія) - Донецьк: Східний видавничий дім, 2013. - 304 с.

13. Кулинич Р.О. Статистична оцінка чинників соціально-економічного розвитку : [монографія] / Р. О. Кулинич. - К. : Знання, 2007. - 311 с.

14. Дослідна справа в агрономії. Навчальний посібник. Статистична обробка результатів агрономічних досліджень. / А.О. Рожков, В.К. Пузік, С.М Каленська, Л.М. Пузік, та ін. Харків, Майдан, 2016. - 341 c.

15. Ткач Є.І. Загальна теорія статистики: підручник [для студ. Вищ. Навч. зал.] / Ткач Є.І., Сторожук В.П. - [3-тє вид.] - К.: Центр навчальної літератури, 2009. - 442 с.

\section{References}

1. S. Detsyura. Vtraty sil'hospproduktsiyi pry zberihanni: vidobrazhayemo operatsiyi v obliku https://ib uh.info/vtrati-silgospprodukci\%D1\%97-pri-zberiganni-vidobrazhayemo-operaci\%D1\%97-v-obliku

2. Zhuk YU.T. Teoretychni osnovy tovaroznavstva/ YU.T. Zhuk, V.A. Zhuk, V.V. Havrylyshyn ta in./ Pidruchnyk. - L'viv: Kompakt-LV, 2009. - $480 \mathrm{~s}$

3. V.A. Koltunov, YE. V. Byelins'ka Tekhnolohiya zberihannya prodovol'chykh tovariv navchal'nyy posibnyk «Vydavnytstvo «Tsentr uchbovoyi literatury» Kyyiv 2014. - 135 s.

4. Koltunov V.A. Tekhnolohiya zberihannya prodovol'chykh tovariv: laboratornyy praktykum N.A. Koltunov. - K. : KNTEU,2003. - $341 \mathrm{~s}$

5. Nikolayeva M. A. Teoreticheskiye osnovy tovarovedeniya: ucheb. dlya vuzov / M.A. Nikolayeva. - M .: Norma, 2007. - $448 \mathrm{~s}$
6. Buzukova Ye.A. Assortiment roznichnogo magazina: Metody analiza i prakticheskiye sovety. I Ye.A. Buzukova. - SPb .: Piter, 2007. - 176 s

7. Holovach A.V., Zakhozhay V.B., Holovach N.A. Statystychne zabezpechennya upravlinnya ekonomikoyu: prykladna statystyka: Navchal'nyy posibnyk. K: KNEU, 2005. - $408 \mathrm{~s}$

8. Matkovs'kyy S.O., Marets' O.R. Teoriya statystyky: Navch. posibnyk. - K.: Znannya, 2010. $-534 \mathrm{~s}$.

9. Ludchenko O.A. Osnovy naukovykh doslidzhen' i patentoznavstvo: navch. posibnyk /O.A. Ludchenko, YU.H. Sukhenko, YA.O. Ludchenko, V.YU. Sukhenko.- 4-te vyd., pererob. i dop. - K.: VDK «Ukrayina», 2011.-237 s.

10. V.A. Koltunov Naukovi doslidzhennya u tovaroznavstvi sil's'kohospodars'kykh produktiv Monohrafiya. N.A. Koltunov, L.M. Puzik, E.R. Ermantraunt, V.YA. Plakhotin Kharkiv, FOP Ivanchenko, 2016, 235 s.

11. Metody yssledovanyy y orhanyzatsyya éksperymentov /pod red. K.P. Vlasova - KH.: Humanyt. tsentr, 2002. $-256 \mathrm{~s}$

12. Bilets'kyy V.S., Smyrnov V.O. Modelyuvannya protsesiv zbahachennya korysnykh kopalyn: (Monohrafiya) - Donets'k: Skhidnyy vydavnychyy dim, 2013. - $304 \mathrm{~s}$.

13. Kulynych R. O. Statystychna otsinka chynnykiv sotsial'no-ekonomichnoho rozvytku: [monohrafiya] / R. O. Kulynych. - K. : Znannya, 2007. - 311 s.

14. Doslidna sprava v ahronomiyi. Navchal'nyy posibnyk. Statystychna obrobka rezul'tativ ahronomichnykh doslidzhen'. / A.O. Rozhkov, V.K. Puzik, S.M Kalens'ka, L.M. Puzik, ta in.. Kharkiv, Maydan, 2016. - $341 \mathrm{~s}$

15. Tkach YE.I. Zahal'na teoriya statystyky: pidruchnyk [dlya stud. vyshch. navch. zal.] / Tkach YE.I., Storozhuk V.P. - [3-tye vyd.] - K.: Tsentr navchal'noyi literatury, 2009. - 442 s.

\section{Аннотация}

\section{Статистические методы оценки естественной убыли массы пищевых продуктов}

\section{Л.М. Пузик, В.К. Пузик}

Рассматривается необходимость выбора и применения математическо-статистических методов и проведения их количественной оценки, которая необходима для принятия решения о возможности их использования в задачах управления качеством при хранении овощной продукции.

Естественная убыль массы возникает на всех этапах товародвижения и является важной составной частью количественных потерь при хранении, транспортировке, погрузочно-разгрузочных работ, реализации.

Основными причинами возникновения естественной убыли массы являются: усыхание или испарения воды; дыхания (только для продуктов, которые относятся к живым объектов); распыления и раструски; крошки, образующиеся при продаже товаров (кроме карамели обычной и сахара-рафинада) разлив; удаления летучей фракции веществ; утечки за счет впитывания жидкой фракции продуктов тарой, упаковочными материалами. При достаточно однородной генеральной совокупности элементами выборки служат типичные экземпляры. 
Партии картофеля, овощей и плодов состоят из физиологически неоднородных образцов, причем эту неоднородность иногда трудно обнаружить по внешним признакам из-за отсутствия объективных критериев видов продукции различных культур. В этом случае выборка составляется в соответствии с принципом случайного отбора, согласно которому все элементы случайной совокупности имеют равные возможности быть отобранными и выбор осуществляется на удачу. Установлено, что во время хранения картофеля в штабелях естественная убыль зависят от уровня ярусов контейнеров. Наименьшие потери массы в первом ярусе штабеля. С увеличением высоты штабеля потери массы растут. Для точного измерения потери массы картофеля сетки для контроля за фактической сохранностью картофеля, в том числе и за естественными потерями, надо закладывать во всех горизонтальных рядах разных уровней (ярусами) контейнеров

Проведенные измерения позволяют определить, каким должен быть объем выборки, чтобы обеспечить требовательную точность оценки естественной убыли массы.

Ключевые слова: естественная убыль массы, генеральная совокупность, выборка, вроде, измерения.

\section{Abstract}

\section{Statistical methods for estimating natural mass loss food}

\section{L.M Pusik, V.K Pusik}

The problems of necessity of selection and application of mathematical-statistical methods and their quantitative estimation, which is necessary for deciding on the possibility of their use in the problems of quality management during storage of vegetable products, are considered.

Natural loss of mass occurs at all stages of the movement of goods and is an important part of quantitative losses during storage, transportation, loading and unloading operations, implementation

The main causes of natural mass loss are: drying or evaporation of water; breathing (only for products related to living objects); spraying and shaking; crumbs formed from the sale of goods (except plain and caramelized caramel); bottling; removal of volatile fraction of substances; impregnation due to absorption of the liquid fraction of products by packaging, packaging materials. Given a sufficiently homogeneous population, the sample items are typical instances.

Batches of potatoes, vegetables and fruits consist of physiologically heterogeneous samples, and this heterogeneity is sometimes difficult to detect on an external basis due to the lack of objective criteria for the types of products of different cultures. In this case, the selection is made according to the principle of random selection, according to which all elements of a random population have equal opportunities to be selected and the choice is made to chance

It has been established that during storage of potatoes in stacks, the natural losses depend on the level of the tiers of the containers. The smallest weight loss in the first tier of the pile. As the height of the stack increases, the weight loss increases. In order to accurately measure the weight loss of the potato netting to control the actual conservation of potatoes, including natural losses, it is necessary to lay in all horizontal rows of different levels (tiers) of container

The measurements made allow us to determine what the sample volume should be in order to provide the exacting accuracy of estimating the natural mass loss.

Keywords: natural mass loss, population, sampling, sample, measurement.

\section{Бібліографрічне посилання/ Bibliography citation: Harvard}

Pusik L.M. and Pusik V.K.(2020) Statistical methods for estimating natural mass loss food. Engineering of nature management, (1(15), pp. 72 - 81.

Подано до редакції / Received: 22.01.2020 